\title{
Obcy we własnej ojczyźnie? Syryjscy Ormianie w Armenii
}

\section{Abstract \\ Aliens in Their own Homeland? Syrian-Armenians in Armenia}

The article presents the current situation of the Syrian-Armenians, who at the same time as refugees and repatriates obtained refuge in Armenia. The article discusses the processes of assimilation of Syrian-Armenians in a new cultural environment. The main goal of the article is to answer the following research questions: to what extent the cultural capital of the diaspora from pre-migration times is reorganized in the new cultural conditions of the host country, how the processes of adaptation and integration of Syrian-Armenians in Armenia are going through and what problems they encounter in the process of cultural assimilation. The empirical data used in this article were collected during the ethnological research in September 2016 in Armenia.

Keywords: Armenia, Syrian-Armenians, Repatriates, Refugees.

\section{Wprowadzenie}

W krajach arabskich w 2010 roku doszło do wybuchu niezadowolenia dużych grup ludności, które domagały się polepszenia warunków życia. Ludzie, którzy wyszli na ulice, zaczęli otwarcie krytykować nepotyzm i korupcję władz, a także ich autokratyczność i rzeczywisty brak swobód obywatelskich. Przyczyny przemian miały podobne podłoże - krytyka polityczna szła w parze $\mathrm{z}$ roszczeniami ekonomicznymi. Ruchy antyrządowe, zapoczątkowane w Tunezji, Egipcie, Libii i Jemenie, wywołały gwałtowne wstrząsy polityczne i społeczne. Wkrótce wydarzenia te, które zainicjowane zostały przez wiele różnorodnych ruchów prote- 
stu na Bliskim Wschodzie, stały się znane pod nazwą „Arabskiej Wiosny”. Fala ruchów antyrządowych wywołała „efekt domina”, docierając szybko do innych państw, między innymi Algierii, Iraku, Libanu, Maroka, Omanu.

Wreszcie, masowe protesty dotknęły również Syryjską Republikę Arabską, a wojna domowa przyjęła tutaj szczególnie krwawą postać. Arabską Wiosnę w wydaniu syryjskim opisuje się często w kategoriach „przelewu krwi” (Górak-Sosnowska 2016: 12) lub bardziej dosadnie jako „największą humanitarną katastrofę obecnego wieku" (O’Rourke 2015: 711; Fedorak 2017: 158). W Syrii, przed wybuchem społecznych niepokojów, wysoki poziom autorytaryzmu uniemożliwiał publiczne wyrażanie poglądów sprzecznych z obowiązującym porządkiem. Między innymi dlatego głośnymi hasłami protestów stały się te namawiające do upadku dyktatury Baszara Al-Asada. Co istotne, Syryjczycy nie byli jednomyślni w swoich apelach domagających się zmian w państwie i żądaniach końca reżimu. Brakowało spójności poglądów oraz solidarności dążeń choćby w takiej skali, jak w Egipcie czy w Tunezji, szczególnie podczas trwania protestów na publicznych placach. Główne miasta Aleppo i Damaszek ze swoimi klasami średnimi i wyższymi nie wspierały swoich rodaków z Hamy i Homs, gdzie odbywała się większość bombardowań. Rozłam w Syrii przebiegał nie tylko wzdłuż linii etnicznych i religijnych, ale także pomiędzy zwaśnionymi grupami klasowymi.Fakt, że większość sprzeciwów wobec autarchii władzy syryjskiej nastąpiła w mniejszych miastach, ilustruje podział istniejący między wspólnotami miejskimi, a także między społecznościami wiejskimi i miejskimi. Wraz z protestami nawołującymi do obalenia Baszara Al-Asada organizowano demonstracje popierające reżim wewnątrz Syrii i poza nią (Totah 2017). W rezultacie wybuchł krwawy konflikt, którego skala przekroczyła granice państwa syryjskiego.

Wkrótce na zgliszczach i części upadającego kraju salaficka organizacja terrorystyczna proklamowała kalifat i utworzyła quasi-państwo - tzw. Państwo Islamskie (ISIS), które objęło swymi rządami także część Iraku. ISIS stało się nie tylko poważnym zagrożeniem dla obywateli tych krajów, ale także - a być może przede wszystkim dla mniejszości etnicznych, narodowych i religijnych często od stuleci zamieszkujących terytoria objęte konfliktem. Mniejszości te stanęły w obliczu niebezpieczeństwa rychłego ludobójstwa. Jedną z takich grup są syryjscy Ormianie, którzy musieli opuszczać swe domy i ratować się ucieczką z owładniętej chaosem Syrii. Wielu z nich przybyło do Armenii, kraju swych przodków. Celem niniejszego artykułu jest przedstawienie obecnej sytuacji syryjskich Ormian,

${ }^{1}$ Jak zauważają niektórzy antropolodzy, określenie „Arabska Wiosna” jest sformułowaniem problematycznym. Pomimo iż nazwa ta stosowana jest $\mathrm{w}$ wielu naukowych opracowaniach, sami Arabowie nie nazywają tych wydarzeń w ten sposób. Dla wielu z nich określenie to jest raczej „retoryczną formułą" charakterystyczną dla zachodniego myślenia o świecie arabskim (Ghoill 2013).Donnchadh Mac an Ghoill, The "Arab Spring" and the Seduction et the Western Left, https:// zeroanthropology.net/2013/08/26/the-arab-spring-and-the-seduction-of-the-western-left/ (dostęp: 06.09.2017). 
którzy jednocześnie jako uchodźcy i repatrianci uzyskali schronienie w Armenii, a także przyjrzenie się z bliska procesom ich asymilacji $\mathrm{w}$ nowym środowisku kulturowym.

W 2012 roku Armenia ogłosiła oficjalnie, że jest gotowa do przyjęcia syryjskich Ormian w swojej historycznej ojczyźnie. Pomiędzy rokiem 2011 a 2015 z Syrii do Armenii przybyło ponad 20 tysięcy Ormian ${ }^{2}$. Według oficjalnych szacunków około 4 tysięcy zdążyło już wyjechać do innych krajów, przede wszystkim do Europy Zachodniej, starając się w nich o azyl i bezpieczny pobyt. Bez wątpienia, Armenia plasuje się w czołówce tych państw, które przyjęły znaczącą liczbę uchodźców z ogarniętej wojną Syrii, jednak w porównaniu z Niemcami czy krajami skandynawskimi Armenia trapiona jest o wiele większymi problemami ekonomicznymi i politycznymi. Skomplikowane układy władzy, nierozwiązany konflikt o Górski Karabach czy wysokie bezrobocie kładą się cieniem na obliczu współczesnej Armenii. Nie bez znaczenia pozostaje fakt, że Armenia jest jednym z najmniejszych krajów Kaukazu, a większość narodu żyje poza jego granicami. Nietrudno więc wyliczyć, że prawie 6 uchodźców przypada na 1000 mieszkańców tego kraju (por. m.in. Grajewski 2017).

\section{Uchodźstwo, repatriacja, asymilacja: metody badań i założenia teoretyczne}

Wojna w Syrii sprawiła, że przedstawiciele diaspory ormiańskiej zostali zmuszeni do opuszczenia swoich domów. Jako niemuzułmańska mniejszość wobec zwiększających się wpływów ISIS i zdobycia przez dżihadystów Aleppo - największego ośrodka diaspory syryjskich Ormian - zaczęli uciekać z terenów ogarniętych konfliktem zbrojnym. Widmo realnego zagrożenia życia wspólnoty i masowy exodus ludności uczynił z syryjskich Ormian uchodźców. Jak zauważyła Dawn Chatty, Syria, która stała się przed laty krajem schronienia nie tylko dla Ormian, ale także innych diaspor (między innymi Kurdów, Palestyńczyków, Irakijczyków), dziś spowodowała jeden z największych kryzysów uchodźczych po II wojnie światowej (Chatty 2017: 12 i inne). Tym samym państwo syryjskie przestało gwarantować etniczno-kulturową ochronę mniejszościom, szczególnie tym niearabskim i chrześcijańskim, do których zalicza się cała ormiańska społeczność. Syryjscy Ormianie, co zauważyła Nicola Migliorino, od czasów dojścia Asadów do władzy

${ }^{2}$ Dane szacunkowe według Ministerstwa Diaspory Republiki Armenii http://www.mindiaspora.am/en/siriahayeri_ankyun (dostęp 17.09.2016). Trzeba powiedzieć, że w trakcie prowadzonych badań terenowych przedstawiciele organizacji pomocowych operowali nieco mniejszymi liczbami dotyczącymi syryjskich Ormian w Armenii. W rozmowach ze mną podawali szacunkowe liczby według własnych ustaleń, które wynosiły od 15 do 17 tysięcy. Należy również dodać, że wraz z syryjskimi Ormianami do Armenii dotarły też inne grupy ludności, jak na przykład Jazydzi, Syryjczycy pochodzenia nieormiańskiego czy Irakijczycy. 
wypracowali pewną formułę milczącego porozumienia z reżimem (Migliorino 2008: 189). Konflikt w Syrii zniweczył taki rodzaj społecznej umowy, a dla znakomitej większości członków diaspory ormiańskiej stał się katalizatorem procesu przymusowej migracji.

Naturalnym kierunkiem ucieczki syryjskich Ormian stała się Armenia, czyli kraj ich przodków. Wiadomo, że od lat różne ośrodki diaspory pielęgnowały i rozwijały więzi ze wspólnotą narodową w Armenii. Ważnym instrumentem tego oddziaływania były rozmaite instytucje, których wsparcie finansowe i materialne miało ogromne znaczenie w okresach ciężkich kryzysów w ojczyźnie (Nieczuja-Ostrowski 2016: 160). W październiku 2012 roku, w obliczu wzrastającej liczby ormiańskich uchodźców z Syrii, armeński parlament wprowadził zmiany ustawodawcze. Jednogłośnie przyjął on poprawki do tak zwanej ustawy „O opłatach państwowych”, zgodnie z którymi cudzoziemcy narodowości ormiańskiej, w których ojczyznach doszło do sytuacji nadzwyczajnej, zagrażającej życiu i zdrowiu, zostali zwolnieni z opłat związanych z uzyskaniem wizy wjazdowej do Armenii oraz odpowiednich dokumentów pobytu tymczasowego. Przed głosowaniem minister diaspory Hrenush Hakobyan podkreślił, że w tym okresie tylko 30 procent syryjskich Ormian posiadało również obywatelstwo Armenii. Co do reszty, która wobec pogarszającej się sytuacji w Syrii nie chciała wyjeżdżać, pojawiły się problemy z przedłużaniem wiz i dokumentów pobytu tymczasowego ${ }^{3}$. W dyskusjach publicznych (włączając $\mathrm{w}$ to dyskursy polityczne i naukowe) syryjskich Ormian zaczęto nazywać nie tylko „uchodźcami”, ale także „repatriantami” powracającymi na ziemie swych przodków (np. Hakobyan 2014; Kubiak 2015; Wróbel 2017). Armenia, która od lat boryka się z problemem emigracji swojego narodu, zaczęła liczyć, że przynajmniej niektórzy uchodźcy/repatrianci osiedlą się tutaj na stałe i tym samym odwrócą negatywne trendy depopulacyjne w ojczyźnie. Rząd w Erywaniu spodziewał się szybkiej asymilacji syryjskich Ormian z mieszkańcami kraju. Asymilacja jako proces „upodobnienia” czy mówiąc wprost „utożsamienia” z kulturą społeczeństwa przyjmującego (Berry 2006: 37 i inne) napotkała jednak wiele problemów. Ormiańskie korzenie i poczucie wspólnoty narodowej nie znalazły prostego przełożenia na sam fakt asymilacji. Polityka diasporyczna obejmująca zaangażowanie kolejnych pokoleń potomków migrantów, którzy nigdy nie mieszkali w ojczyźnie (Vertovec 2012: 104), okazała się niewystarczająca.

Dane empiryczne wykorzystane $\mathrm{w}$ tym artykule zostały zebrane podczas badań terenowych, które przeprowadziłem we wrześniu 2016 roku w Armenii. $\mathrm{W}$ tym okresie zrealizowałem 30 ustrukturyzowanych i pogłębionych wywiadów etnograficznych z uchodźcami z Syrii, głównie przybyłymi z okolic Aleppo, Damaszku, Ar-Rakki i Latakii. Przygotowany kwestionariusz wywiadu dotyczył trzech zasadniczych obszarów: sytuacji członków diaspory ormiańskiej w Syrii przed wybuchem wojny, ich wymuszonego powrotu do ojczyzny oraz proble-

${ }^{3}$ Korzystałem z danych opublikowanych przez Portal Arcana: http://www.portal.arcana.pl/ Armenia-zaprasza-ormian-zyjacych-w-syrii,3332.html (dostęp 06.09.2016). 
mów adaptacji i integracji w Armenii. Większość pytań miała charakter otwarty, ograniczony jedynie dyspozycjami wywiadu, co pozwalało moim rozmówcom na udzielanie swobodnych odpowiedzi. Rozmowy z syryjskimi Ormianami odbywały się w języku angielskim lub wschodnioormiańskim tłumaczonym na język polski. Rozmawiałem również z pracownikami organizacji pozarządowych, którzy zajmują się bezpośrednią pomocą dla uchodźców z Syrii. Byli to głównie przedstawiciele „Help Your Brother” Charitable Foundation kierowanej przez Tatula Harutyuniana, której siedziba mieści się w Erywaniu. Organizacja ta od początku konfliktu w Syrii aktywnie wspiera Ormian przybyłych masowo do Armenii oraz udziela pomocy tym, którzy pozostali w Aleppo i innych syryjskich miastach.

Całość jakościowych badań etnograficznych przeprowadzona została w Erywaniu. To właśnie stolica Armenii stała się dla większości syryjskich Ormian ich „nowym domem”. Erywań pełni bowiem dominującą rolę jedynego wielkomiejskiego ośrodka kraju, gdzie żyje 1/3 jego mieszkańców i ulokowane są najważniejsze instytucje państwowe (Siekierski 2014: 16). Rozmowy z respondentami odbywały się głównie w przestrzeni miasta. Były to przede wszystkim sklepy, pasaże handlowe, bary i restauracje prowadzone przez uchodźców z Syrii. Wykorzystałem także sieć kontaktów i znajomości wśród samych migrantów. Informacje z wywiadów starałem się odnosić i porównywać z obserwacjami, które prowadziłem podczas spotkań z moimi respondentami i w trakcie ich codziennych zajęć.

Wykorzystałem - chociaż w wyraźnie mniejszym stopniu - materiały zastane, głównie dane statystyczne dotyczące liczby uchodźców w Armenii, strony internetowe, informacje na temat polityki państwa i działalności organizacji pozarządowych wobec syryjskich Ormian, jak również projektów osadniczych. W ujęciu metodologicznym bliskie mi było stanowisko, które przed laty spuentował Max Weber, a mianowicie, że badanie zjawisk kulturowych wiąże się nie tyle z ich opisem, ile z kontekstualnym rozumieniem (w ujęciu Verstehen). Droga badawcza zostaje wytyczona nie tylko przez narracje i opowieści badanych, lecz także poprzez różnorakie złożone konteksty zjawisk, które im towarzyszą (Abel 1948: 211). Potocznie ujmowany „problem uchodźców syryjskich” jawi się jako "problem międzynarodowy", niemniej jednak często rozpatrywany bywa "jednowymiarowo" (na przykład w kontekście dyskursów medialnych czy politycznych), w praktyce zaś ma charakter o wiele bardziej złożony i „osobliwy”, tak jak w przypadku syryjskich Ormian w Armenii.

W niniejszym artykule staram się odpowiedzieć na kilka zasadniczych pytań badawczych, a mianowicie: (1) w jakim stopniu kapitał kulturowy diaspory z czasów przedmigracyjnych reorganizuje się w nowych warunkach kulturowych kraju przyjmującego, (2) jak przebiegają procesy adaptacji i integracji syryjskich Ormian w Armenii, (3) jakie problemy dotykają ich w procesie asymilacji kulturowej? Aby odpowiedzieć na powyższe pytania, w pierwszej kolejności rekonstruuję historyczne podstawy diaspory ormiańskiej w Syrii. W dalszych częściach artykułu analizuję politykę władz Armenii, udział organizacji pozarządowych i między- 
narodowych instytucji mających swój wkład w procesy osiedlania się syryjskich Ormian na Kaukazie. Wreszcie prezentowany tekst koncentruje się na problemach osadniczych, mieszkaniowych i pracy, które świadczą o rzeczywistym stanie oraz poziomie asymilacji syryjskich Ormian ze społeczeństwem armeńskim.

Na tym tle staram się uwzględnić zarówno specyfikę badanej grupy diasporalnej, jak i transnarodowy kontekst mający wpływ na jej współczesne oblicze. Należy bowiem pamiętać, że przykład syryjskich Ormian uciekających do Armenii jest $\mathrm{w}$ dużej mierze nietypowy, ponieważ kraj ten przyjmował przede wszystkim obywateli Syrii, którzy byli pochodzenia ormiańskiego. Tym samym przesiedlenia tej konkretnej grupy do ojczyzny ich przodków zaczęły przypominać procesy związane z repatriacją (por. m.in. Davtyan 2017). W badaniach nad kwestią asymilacji syryjskich Ormian w Armenii wykorzystuję teoretyczną koncepcję diaspory rozumianej jako „rezerwa kulturowa” (Safran 2005). Często wspólnota diaspory zachowuje narodowe wartości „nieskażone” aktualnymi ideologiami ojczyźnianymi - poczucie tożsamości narodowej członków diaspory opiera się na kilku filarach kulturowych, które nie muszą wcale być zbieżne z poczuciem narodowej tożsamości współbraci żyjących w ojczyźnie ${ }^{4}$. Dzieje się tak, gdy diaspora ma swobodę wyrażania własnych wartości, a rząd kraju przyjmującego w pełni toleruje jej odrębność kulturową. Pomimo iż Syria od momentu przejęcia władzy przez rodzinę Al-Asada jest uznawana za dyktaturę, społeczność ormiańska zachowała w państwie syryjskim liczne prawa dające jej szerokie możliwości praktykowania własnej religii czy języka ojczystego. Wybuch wojny domowej w Syrii obwieścił kres bezpiecznej egzystencji dla ormiańskiej mniejszości.

Obecność syryjskich Ormian w Armenii pokazała nie tylko rzeczywisty obraz wspólnoty tożsamości pomiędzy diasporą a narodem żyjącym w państwie, ale uzewnętrzniła wiele różnic, które skomplikowały sam proces akulturacji. Świadomość diasporyczna z zachowaną wizją własnej ojczyzny musiała ulec redefinicji. „Bagaż kulturowy” diaspory, o którym pisze William Safran (2005), okazał się przykładem „idealnego bytu wyobrażeniowego” zarówno narodu, jak i państwa, a rozczarowanie nową sytuacją i pobytem w Armenii utrudniło proces „,naturalizacji” syryjskich Ormian w „kraju ich przodków”.

${ }^{4}$ Dla syryjskich Ormian tożsamość kulturowa kształtuje się w kontekście wspólnoty losów związanej przede wszystkim z ludobójstwem Ormian z 1915 r., odrębności językowej oraz religijnej. W trakcie rozmów przedstawiciele diaspory ormiańskiej z Syrii prawie zawsze podkreślali, że są bardziej religijni niż ich pobratymcy żyjący w Armenii, a język zachodnioormiański, którym się posługują, uniknął wielu wpływów zewnętrznych (np. języka rosyjskiego) w odróżnieniu od języka wschodnioormiańskiego używanego przez mieszkańców Armenii. Yossi Shain i Tamara Cofman Wittes zauważyli też, że obawy ojczyzn często odbiegają od obaw ich diaspor. Obywatele Armenii są bardziej skłonni do ustępstw na rzecz Turcji i Azerbejdżanu, podczas gdy dla ormiańskiej diaspory pamięć o ludobójstwie $\mathrm{w}$ istotny sposób rzutuje na relacje zewnętrzne $\mathrm{z}$ innymi społeczeństwami, szczególnie z tymi, które uznane zostały za sprawców zagłady (por. m.in. Nieczuja-Ostrowski 2016: 145-186). 


\section{Ormiańska diaspora w Syrii}

Terytorium Armenii ze względu na swoje położenie geopolityczne w ciągu wieków stanowiło kość niezgody między wielkimi imperiami i obiekt licznych najazdów Arabów, Turków Seldżuckich i Tataro-Mongołów. W rezultacie Ormianie byli zmuszeni emigrować $\mathrm{w}$ nadziei na znalezienie bezpiecznego schronienia w ościennych lub dalekich krajach (Stepanian 2014: 37). Sytuacja ta sprzyjała rozszerzaniu się ormiańskiej diaspory na coraz to nowe państwa Europy, Azji i Afryki. Jednym $z$ takich krajów, w których uformowała się liczna diaspora ormiańska, była Syria. Z czasem syryjscy Ormianie zyskiwali uznanie wśród Syryjczyków. W różnych okresach historycznych pomagali Arabom w walkach o ich niepodległość. W drugiej połowie XIX wieku w czasie Nahdy, czyli arabskiego renesansu, który przyczynił się do narodowego, kulturowego i politycznego rozkwitu Syrii, naród ormiański odegrał ważną rolę. Wielu Ormian zostało oficerami w Syryjskiej Republice Arabskiej, inni współtworzyli arabski teatr, jak Adib Ishak, lub stawali się pionierami arabskiego dziennikarstwa politycznego, jak Rzkallah Hasun (Pashayan 2009).

Chociaż w Syrii Ormianie mieszkali od czasów starożytnych (por. m. in. Zakrzewska-Dubasowa 1990: 98-99 i inne), to początek kształtowania współczesnej ormiańskiej diaspory w tym kraju należy wiązać z prześladowaniami i deportacjami Ormian w 1915 roku. W tym czasie dawna ormiańska społeczność znacząco powiększyła się o emigrantów uciekających przed ludobójstwem z Imperium Osmańskiego, a następnie z Cylicji. Ormiańska enklawa w Syrii, zwana Hayy al-Arman (Dzielnica Ormiańska), liczyła ponad 220 tysięcy (Campos 2016: 13). Ludność ormiańska koncentrowała się przede wszystkim w miastach syryjskich, zajmując się handlem, rzemiosłem i usługami. Największe skupiska mniejszości ormiańskiej ulokowały się w Aleppo (około 70 tysięcy) oraz w Al-Kamiszli, Damaszku, Latakii, Ar-Rakka, Al-Hasaka i Dajr az-Zaur (Migliorino 2008: 33 i inne). Przed Arabską Wiosną oficjalnie mówiono natomiast, że w Syrii mieszka ponad 100 tysięcy Ormian.

Jak napisał Simon Payaslian, syryjscy Ormianie przebyli ciężką i trudną drogę, aby przekształcić swój status z uchodźców w diasporę (Payaslian 2007: 92-93). Zasadniczo byli oni dobrze przyjmowani i traktowani przez społeczeństwo syryjskie. Pomimo że stanowili grupę mniejszościową, to w znaczący sposób przyczynili się do rozwoju demograficznego, ekonomicznego i społecznego państwa syryjskiego. Po traumie ludobójstwa syryjscy Ormianie ciężko pracowali, aby odbudować swoje życie, zachowując przy tym własną kulturę, tradycje i pamięć o tragicznej przeszłości. Już pierwszemu pokoleniu uchodźców udało się powołać w Syrii lokalne struktury organizacji diasporalnych, takich jak pomocowa organizacja Armenian General Benevolent Union (Ogólnoormiańskie Zjednoczenie Organizacji Charytatywnych) czy centrolewicowa partia polityczna Armenian Revolutionary Federation (Armeńska Federacja Rewolucyjna znana również 
jako dasznacy). Z powodzeniem zaczęli rozwijać własne przedsiębiorstwa, stając się szybko uznanymi rzemieślnikami, jubilerami, restauratorami, mechanikami i budowniczymi. W Aleppo i Damaszku, a także innych syryjskich miastach funkcjonowały szpitale, biblioteki, teatry, szkoły językowe i kluby sportowe prowadzone przez Ormian (Campos 2016: 13-14). Jedynym poważnym problemem był dla nich arabski nacjonalizm, który przybierał na sile wówczas, gdy sytuacja polityczna i gospodarcza Syrii się pogarszała (Lust-Okar 1996: 58).

Ormiańska diaspora skonsolidowała się przede wszystkim wokół religii i języka, co wyróżniało ją w państwie muzułmańskim. W Syrii do momentu wybuchu wojny domowej i ekspansji tzw. Państwa Islamskiego swobodnie współistniały z sobą różne odłamy chrześcijańskie, jak Ormiański Kościół Apostolski, który posiadał dwie diecezje w Aleppo i Damaszku, oraz Ormiański Kościół Katolicki. Niektórzy przynależeli również do wspólnot ewangelicznych (Pashayan 2009). Istniała silna współpraca pomiędzy ormiańskimi Kościołami apostolskimi, katolickimi i ewangelicznymi. Każdego roku wspólnymi siłami organizowano rocznicowe obchody upamiętnienia ludobójstwa z 1915 roku. Na co dzień językiem używanym przez syryjskich Ormian pozostał język armeński w odmianie zachodnioormiańskiej, różniącej się nieco od języka wschodnioormiańskiego, czyli oficjalnego języka dzisiejszej Armenii. Ormianie mieszkający w Syrii mieli możliwość zachowania swej narodowej tożsamości poprzez edukację i szkolnictwo. Istniały bowiem żłobki, przedszkola i szkoły, w których można było uczyć się religii, literatury i języka ormiańskiego. Dalsza edukacja odbywała się w szkołach arabskich lub prywatnych. Edukacja narodowa rozwijała się również w licznych związkach sportowych i kulturalnych (na przykład Tekeyan, „Nowa Generacja”, Narodowe Stowarzyszenie Kultury), natomiast na co dzień etniczna odrębność pielęgnowana była $\mathrm{w}$ rodzinach. Ponadto Ormianie rozwijali swoje instytucje polityczne mające wpływy w państwie syryjskim. Niekiedy przedstawiciele mniejszości ormiańskiej zasiadali w parlamencie (Pashayan 2009). Tym samym syryjscy Ormianie nigdy nie ulegli asymilacji ani też nigdy nie zerwali silnych więzi z kulturą kraju swego pochodzenia.

Dobra organizacja diaspory ormiańskiej w Syrii odbiła się na ich statusie ekonomicznym: 16\% syryjskich Ormian stanowiło klasę zamożnych obywateli Syrii, a około 65\% - klasę średnią (Hakobyan 2014). W państwie rządzonym przez Asadów mogli oni liczyć na ochronę. W tym miejscu należy dodać, iż korzenie rodziny Asadów wywodzą się od mniejszości Alawitów, którzy w latach 70. XX wieku zwyciężyli w rywalizacji o władzę w państwie i wprowadzili autorytarne rządy (van Dam 2011: 68 i inne). W wywiadach etnograficznych syryjscy Ormianie w większości nie kryli swego poparcia politycznego dla Baszara Al-Asada, poddając krytyce rezultaty Arabskiej Wiosny. Wojna domowa w Syrii przeciwko prezydentowi Baszarowi Al-Asadowi, a w praktyce bratobójcza walka i napór Państwa Islamskiego przyniosły poważne zagrożenie dla ormiańskiej wspólnoty. Pogarsza- 
jąca się sytuacja w Syrii i ponowne widmo ludobójstwa sprawiło, że w 2011 roku syryjscy Ormianie zaczęli masowo opuszczać kraj owładnięty wojną.

\section{Powrót syryjskich Ormian do Armenii}

Armenia w czasach Związku Radzieckiego była jego najmniejszą republiką. Uzyskanie niepodległości, które nastąpiło 21 września 1991 roku, zostało okupione cierpieniem Ormian. W walce o niepodległość istotną rolę odegrała wojna z Azerbejdżanem, w wyniku której Armenia została poddana przez Turcję blokadzie gospodarczej i politycznej. Do dziś Turcja i Armenia nie nawiązały z sobą stosunków dyplomatycznych, a granica między nimi jest zamknięta. Napięte stosunki, a także zamknięte granice oraz stan wojny utrzymują się w relacjach z Azerbejdżanem. Spór o Górski Karabach - ormiańską enklawę formalnie przynależną Azerbejdżanowi - wciąż stanowi ognisko zapalne w regionie kaukaskim. Trzeba również pamiętać, że krótko przed uzyskaniem niepodległości, 7 grudnia 1988 roku, w Armenii nastąpiło tragiczne trzęsienie ziemi w Gyumri. Zginęło w nim 25 tysięcy osób, a pół miliona odniosło rany. Pamięć o tej traumie jest wciąż żywa wśród Ormian i bywa ona porównywana z ludobójstwem z 1915 roku (Szagojan 2014: 121). W tych tragicznych warunkach przyszło Ormianom tworzyć niepodległe państwo i poszukiwać nowych warunków do jego rozwoju.

Zagadnienia transformacyjne ciągle odciskają swoje piętno na niełatwej sytuacji politycznej i gospodarczej Armenii. Stwierdzenie, że kraj ten jest ciągle w fazie transformacji systemowej (od społeczeństwa socjalistycznego do społeczeństwa kapitalistycznego), bywa podnoszone przy okazji różnych dyskusji publicznych dotyczących kwestii ekonomiczno-społecznych oraz polityki wewnętrznej i zewnętrznej państwa (Fedorowicz 2017). Problemy te bezpośrednio przekładają się na jakość życia mieszkańców Armenii i sprzyjają emigracji zarobkowej Ormian: w roku 1991 liczba ludności wynosiła ponad trzy i pół miliona, a dziś niewiele ponad trzy miliony ${ }^{5}$. Oznacza to, że ormiańska polityka koncentrowała się przede wszystkim na problemie emigracji własnego narodu. Wojna w Syrii przeorientowała tę politykę, a kwestia uchodźców z Bliskiego Wschodu zajęła w niej istotne miejsce. W 2012 roku premier Armenii Tigran Sarkisian ogłosił, że kraj jest gotowy przyjąć syryjskich Ormian, zapewniając im bezpieczne schronienie, jednakże pomimo tej otwartości oferowana pomoc dla uchodźców była niewystarczająca. Ograniczone możliwości finansowe państwa sprawiły, że rząd w Erywaniu nie był w stanie samodzielnie zagwarantować odpowiedniej opieki.

Syryjscy Ormianie przybywali do Armenii różnymi sposobami. Władze uruchomiły transport lotniczy na trasach Aleppo - Erywań, Damaszek - Erywań

${ }^{5}$ Najnowsze dane demograficzne według: https://www.populationpyramid.net/pl/armenia/2017/ (dostęp 14.10.2017). 
i Bejrut - Erywań. Zorganizowały także transporty autokarowe na linii Aleppo Erywań. Niektórzy samoorganizowali się i przybywali do stolicy Armenii własnymi samochodami. Władze dokonały uproszczeń wizowych. Syryjscy Ormianie, którzy wprowadzili się do Armenii, mogli zarówno uzyskać prawo do długoterminowego dokumentu pobytowego, jak i szybko otrzymać ormiańskie obywatelstwo. Wydawanie dokumentów pobytowych i wiz odbywało się bezpłatnie. W swojej historycznej ojczyźnie zostali potraktowani zarówno jak repatrianci, jak i uchodźcy wyparci przez syryjski konflikt. W rzeczywistości jednak nie funkcjonowały skoordynowane mechanizmy „przepływów migrantów”. Obecnie brakuje różnorodnych danych docelowych na temat uchodźców lub są one mocno rozproszone: występują sprzeczne informacje, ile dokładnie przybyło osób w poszczególnych latach, ilu było mężczyzn, a ile kobiet i dzieci, jakie problemy mieli syryjscy Ormianie zaraz po przybyciu i później?

Najwięcej syryjskich Ormian wybrało możliwość podwójnego obywatelstwa, które pozwalało im na swobodne przemieszczanie się do innych krajów. W latach 2012-2014 jedynie 7\% wybrało status uchodźcy (Hakobyan 2014). W 2016 roku minister diaspory Hranusz Hakobyan potwierdził, że do Armenii przybyło już 20 tysięcy syryjskich Ormian. Z tej grupy zdążyło już opuścić Armenię ponad 4 tysiące uchodźców (por. między innymi Davtyan 2017). Jak wspomniałem wcześniej, według nieoficjalnych danych pozyskanych w trakcie badań terenowych od przedstawicieli pozarządowych organizacji pomocowych liczba uchodźców z Syrii, którzy opuścili Armenię, może być przynajmniej dwa razy większa. Zatem znacząca część syryjskich Ormian potraktowała Armenię jako kraj „tranzytowy" w swojej wędrówce. Z uchodźców oraz repatriantów stali się emigrantami i rozjechali się po świecie. Proces „naturalizacji” syryjskich Ormian, którego przypieczętowaniem miało być otrzymanie armeńskiego obywatelstwa i stałe osiedlenie w ojczyźnie, okazał się dla nich zbyt trudny. Niewystarczająca liczba mieszkań, brak miejsc pracy i duże bezrobocie, a także niskie zarobki i korupcja urzędników - spowodowały rozczarowanie pobytem w Armenii. Poczucie wspólnej tożsamości, historii i pochodzenia podzielane zarówno przez syryjskich, jak i kaukaskich Ormian w wielu przypadkach nie znalazło bezpośredniego przełożenia na asymilację w nowej rzeczywistości.

\section{Problemy adaptacyjne syryjskich Ormian}

Z przeprowadzonych rozmów wynika, że dla syryjskich Ormian największymi problemami zaraz po przyjeździe do Armenii było zdobycie pracy i mieszkania. Zdecydowana większość z nich osiedliła się w Erywaniu. W ramach pomocy państwowej około 911 rodzin otrzymało tymczasowe mieszkania, około 72 rodzin mieszka w pensjonatach Ormiańskiego Kościoła Katolickiego, około 24 rodzin żyje w domach swoich dobroczyńców (dane według Armeńskiego Ministerstwa Dia- 


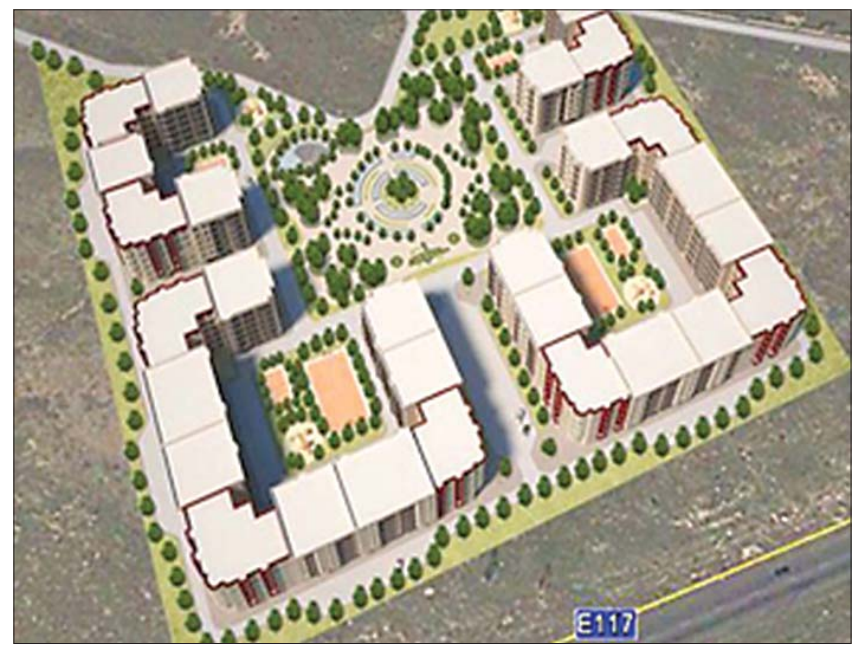

Projekt Nowe Aleppo - plan osiedla, źródło: Periodical of the RA Ministry of Diaspora, http://hayernaysor.am/en/archives/15890 (dostęp 14.09.2016)

spory, 2014), jednak większość „na własną rękę” wynajmuje mieszkania. Co nie jest bez znaczenia, w Erywaniu od momentu przybycia syryjskich Ormian ceny wynajmu mieszkań gwałtownie wzrosły. Odpowiedzią na bolączki mieszkalnictwa dla uchodźców miał być rządowy projekt budowy nowego miasta o nazwie Nowe Aleppo.

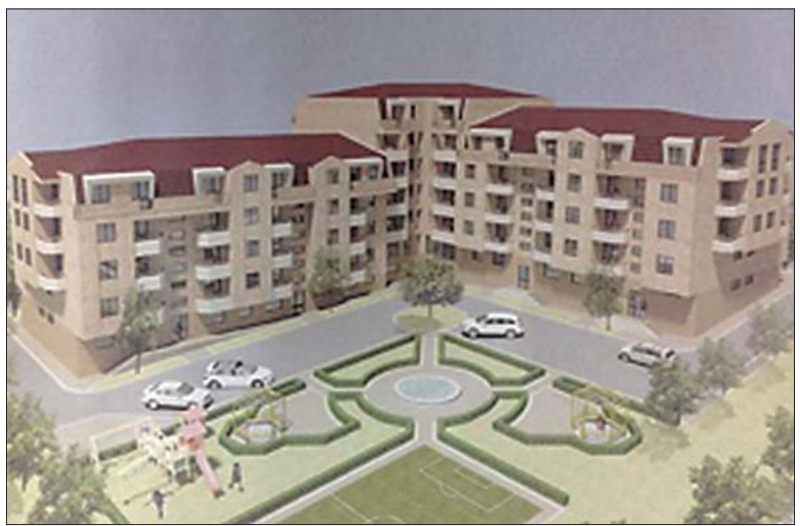

Projekt Nowe Aleppo - wizualizacja i zagospodarowanie terenu Periodical of the RA Ministr of Diaspora, http://hayernaysor.am/en/archives/date/2013/12/12 (dostęp 14.09.2016)

Budynki miały zostać zlokalizowane $20 \mathrm{~km}$ za Erywaniem, w pobliżu miejscowości Ashtarak. Nowi osadnicy podeszli jednak do projektu z dużą rezerwą. Po pierwsze, niemałą część kosztów ponieść mieli sami repatrianci, po drugie, nie 
chcieli osiedlić się poza Erywaniem (wcześniej znakomita większość z nich mieszkała w dużych syryjskich miastach), po trzecie zaś, czas oczekiwania na nowe mieszkania był zbyt długi (cały projekt rozciągnięty został na lata). W rezultacie Nowe Aleppo pozostaje wciąż w sferze planów architektonicznych. Zamiast tego w Armenii funkcjonują projekty budowy mieszkań, które oferowane są przez rozmaite fundacje i stowarzyszenia.

Te jednak - mimo że budują domy dla syryjskich uchodźców na preferencyjnych warunkach - w praktyce sprzedają je po cenach niewiele różniących się od cen mieszkań na wolnym rynku.

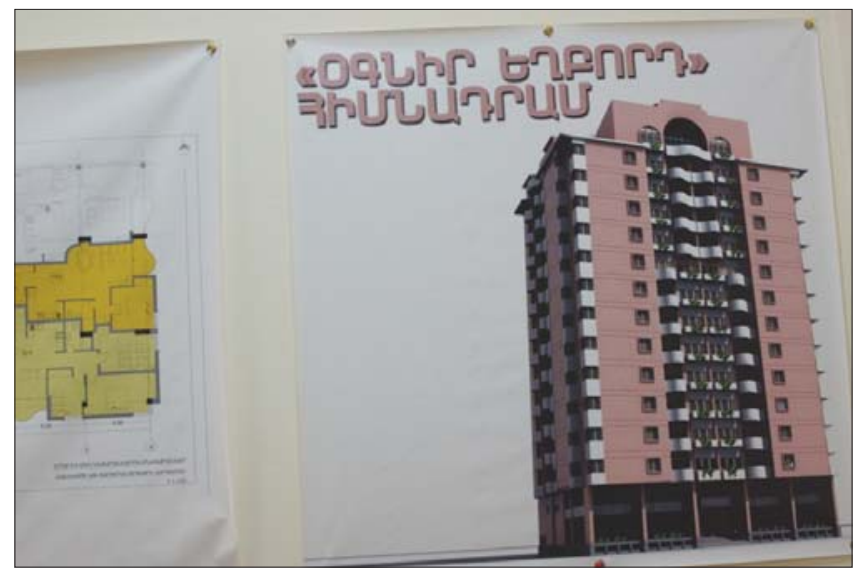

Projekt domu dla syryjskich Ormian realizowany przez „Help Your Brother” Charitable Foundation, fot. Adam Pomieciński

Ogólnie rzecz ujmując, dzisiaj około $88 \%$ syryjskich Ormian wynajmuje mieszkanie, a tylko $12 \%$ zdecydowało się na zakup własnego lokalu (dane według Armenian General Benevolent Union, 2013-2014). Warto dodać, że dawno skończyły się dotacje na te cele, pozyskiwane między innymi z programów ONZ (pokrycie kosztów wynajmu za pierwsze 6 miesięcy pobytu) czy wsparcia Armenian General Benevolent Union (pokrycie kosztów wynajmu za 3 miesiące dla 350 rodzin) (por. Ter-Grigoryan 2013: 8). Osobną kwestią pozostaje osadnictwo syryjskich Ormian w Górskim Karabachu, które wzbudziło ostre protesty Azerbejdżanu na arenie międzynarodowej. W rzeczywistości skala tego zjawiska jest niewielka, w odróżnieniu od jego wydźwięku politycznego. Syryjscy uchodźcy zjawili się w Karabachu już w 2012 roku. Około 50 rodzin przybyło gównie z prowincji Latakii i osiedliło się w rejonie południowego Karabachu (Askeran, Lisogorsk, Kovsakan). W odróżnieniu od repatriantów przebywających w Armenii (preferujących niemal wyłącznie życie w wielkim mieście) syryjscy uchodźcy zajmują się w Karabachu głównie rolnictwem. 
Nie mniej istotnym problemem dla syryjskich Ormian jest znalezienie pracy. W Armenii, w której panuje 40\% bezrobocie, praca jest „towarem deficytowym”. W tym obszarze działania władze były jeszcze mocniej ograniczone niż w przypadku projektów osadniczych. Programy państwowe skupiały się na próbach aktywizacji i bezpłatnych szkoleniach dla stosunkowo niewielkich grup repatriantów z Syrii, np. 60 farmaceutów uczestniczyło w specjalnych kursach w Ministerstwie Pracy i Spraw Socjalnych, 70 ekonomistów wzięło udział w szkoleniach Banku Centralnego Armenii, około 950 osób otrzymało zatrudnienie przy pracach interwencyjnych i publicznych (dane według Komitetu Koordynacyjnego ds. Syryjsko-Armeńskich, 2014). Zdecydowana większość musiała radzić sobie sama. Ci, którym udało się odnaleźć na trudnym armeńskim rynku pracy, zatrudnili się w hotelach, sklepach, barach i restauracjach. Niektórzy postanowili otworzyć własne firmy (np. serwisy i warsztaty samochodowe), innym udało się założyć niewielkie zakłady rzemieślnicze (np. zakład produkujący i sprzedający obuwie, zakłady fryzjerskie, zakłady szewskie, zakłady odzieżowe), zaś najwięcej powstało małych sklepów i barów mających w swej ofercie tradycyjne dania kuchni syryjskiej i ormiańskiej.

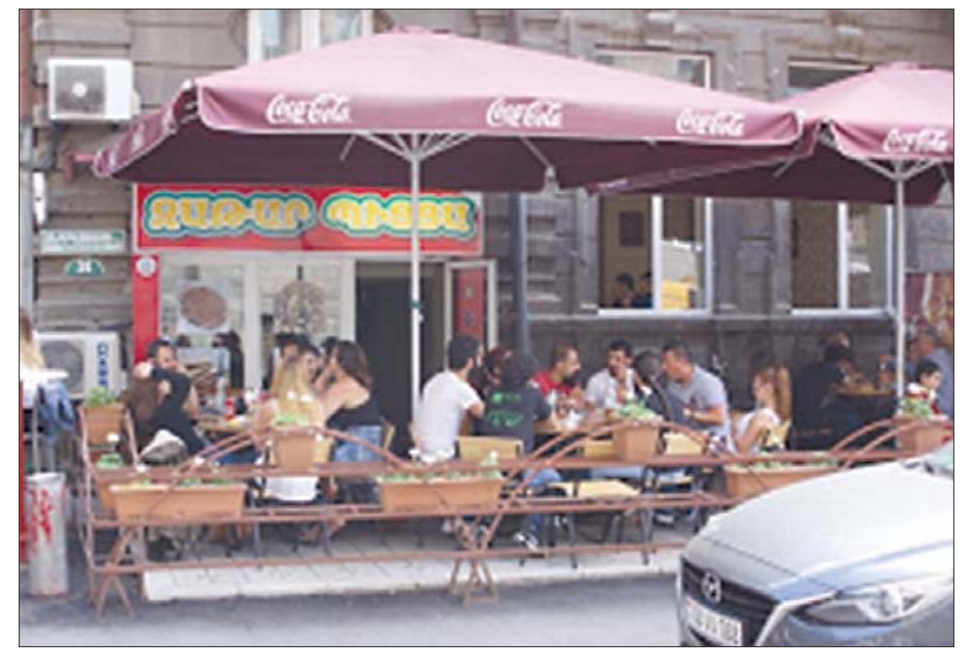

Bar prowadzony przez syryjskich Ormian na jednej z ulic Erywania, fot. Adam Pomieciński

Obecnie powstał też projekt ułatwiający prowadzenie własnych firm przez wykwalifikowanych mechaników samochodowych. Na obrzeżach Erywania już zostały wykupione specjalne działki, na których zostanie zlokalizowanych kilkanaście warsztatów samochodowych. Paradoksalnie pomysł ten zrodził się nie w instytucjach państwowych, lecz w fundacjach zajmujących się pomocą dla syryjskich repatriantów. 


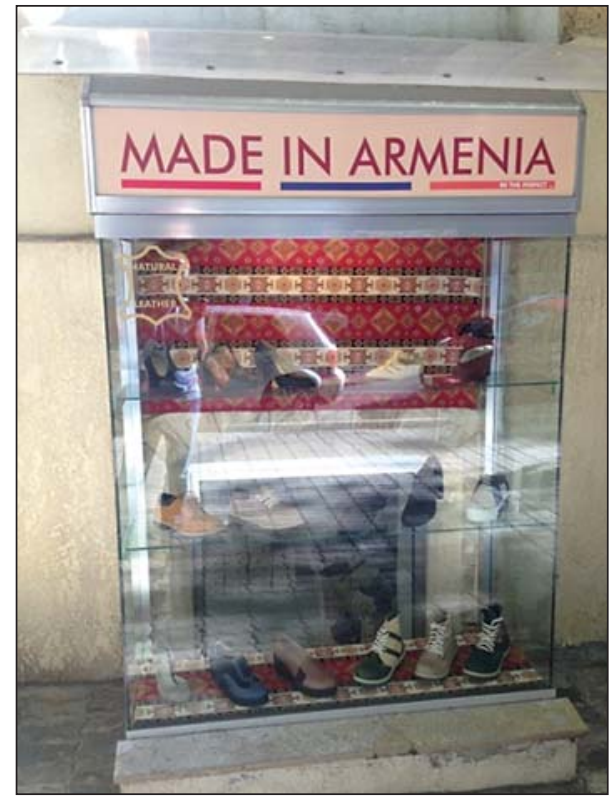

Sklep syryjskich Ormian w Erywaniu z butami własnej produkcji, fot. Adam Pomieciński

Syryjscy Ormianie, którzy w Aleppo, Damaszku czy Latakii prowadzili swój własny biznes, po przybyciu do Erywania chcieli robić to samo. Zderzyli się jednak boleśnie z realiami armeńskimi, które są równie dokuczliwe dla miejscowych Ormian. Wysokie podatki, mały rynek zbytu, niewielka siła nabywcza społeczeństwa armeńskiego, a także biurokracja i korupcja urzędników stanowiły długą listę poważnych utrudnień dla przedsiębiorców. W obliczu tego integracja strukturalna nie mogła być dobrze zrealizowana. Brak pracy i słabe perspektywy ekonomiczne stały się głównymi powodami wyjazdu dużej grupy syryjskich Ormian z Armenii.

Ważną funkcję włączającą syryjskich Ormian do społeczeństwa armeńskiego pełni także system edukacyjny. Jak wiadomo, syryjscy Ormianie mówią językiem zachodnioormiańskim, który różni się od wschodnioormiańskiego oficjalnie używanego w Armenii. W kraju powszechnie jest używany także język rosyjski, którego przybywający z Syrii Ormianie nie znają. Edukacja językowa dla syryjskich Ormian, która miała na celu niwelować te problemy, została wprowadzona nie tylko w szkołach dla dzieci, ale również była realizowana dla dorosłych na specjalnych kursach języka ormiańskiego i rosyjskiego. Te jednak nie cieszyły się popularnością wśród dorosłych i młodzieży. Specjalnie dla syryjskich dzieci otworzono szkołę, która nazywała się Kilikia. Funkcjonowała ona jedynie rok, po czym zadecydowano o jej zamknięciu i wysłaniu dzieci syryjskich Ormian do armeńskich szkół. W opiniach syryjskich Ormian nauka w szkołach państwowych (szczególnie w pierwszych miesiącach po przybyciu) była trudna. Wynikało to $\mathrm{z}$ różnic 
między systemem edukacji w Syrii i Armenii. W szkołach syryjskich większość przedmiotów była wykładana w języku arabskim. Po ormiańsku rozmawiano na lekcjach języka ojczystego (około 4 godziny tygodniowo) i religii (około 2 godzin tygodniowo). W Armenii największe kłopoty wiązały się z nauczaniem przedmiotów ścisłych, jak matematyka czy przyroda. Uczniowie musieli przyswoić nowe dla siebie nazewnictwo i terminologię. Te problemy na bieżąco starali się rozwiązywać dyrektorzy szkół, wprowadzając dla nich chociażby dodatkowe zajęcia i korepetycje.

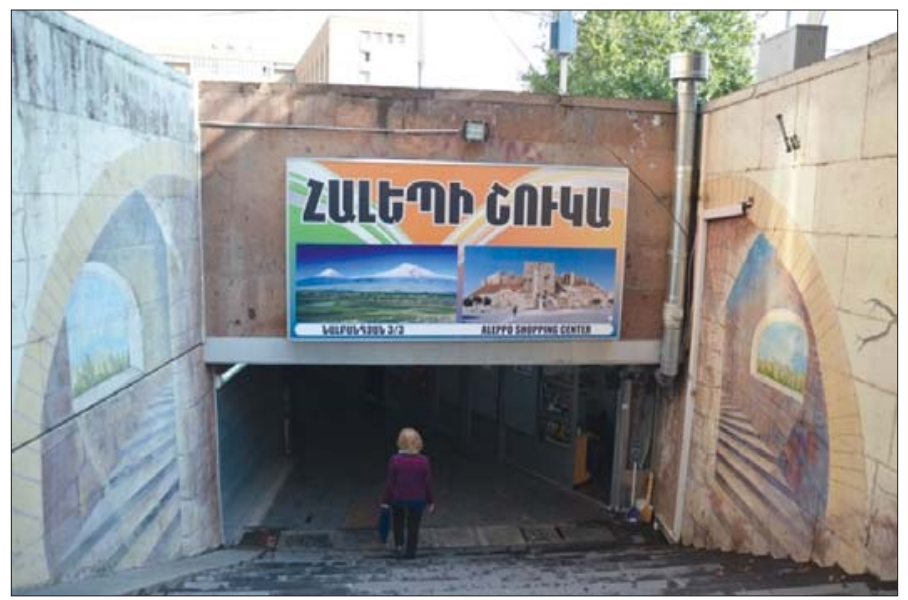

Centrum Handlowe Aleppo w Erywaniu, fot. Adam Pomieciński

Wraz z przybyciem syryjskich Ormian do Armenii aktywne stały się organizacje pozarządowe, które zaczęły wdrażać programy pomocowe dla uchodźców. Realizacją projektów międzynarodowych, które w większości były nastawione na pomoc podstawową i humanitarną dla uchodźców, zajęły się między innymi: Koordynacja Problemów Syryjskich Ormian, Misja Armenii, „Help Your Brother" Charitable Foundation, a także Ormiański Czerwony Krzyż i Ormiański Caritas. Programy pomocy żywnościowej realizowane były przez władze Kuwejtu i Światowy Program Żywnościowy (WFP), a Misja Armenii wspólnie z ONZ koordynowała programy rekompensaty 6-miesięcznych czynszów dla syryjskich Ormian.

Obok międzynarodowych programów wsparcia rozpoczęto wdrażanie programów pomocowych oferowanych przez światową diasporę ormiańską. Te, w odróżnieniu od programów wsparcia międzynarodowego, mają charakter długofalowy, a ich celem jest pomoc i aktywizacja syryjskich Ormian w społeczeństwie armeńskim. Na tym tle wyróżnić można Fundację Gulbenkiana, która wraz z rządem Armenii wspiera syryjskich studentów na uniwersytetach armeńskich (około 350 syryjskich Ormian otrzymuje zwrot czesnego). Wiele inicjatyw pomocowych jest 
organizowanych przez Armenian General Benevolent Union. Dzięki niej zostało ufundowanych kilkaset stypendiów dla syryjskich uczniów i studentów, uruchomiono w Erywaniu przychodnię lekarską dla uchodźców, w której pracę znaleźli syryjscy lekarze. Niemal każdego miesiąca są finansowane procedury medyczne dla uchodźców w Armenii, których nie pokrywa budżet państwa. Wśród NGOsów bardzo aktywna jest organizacja Syrian Armenian Relief Fund, która zajmuje się głównie zapewnieniem pomocy finansowej, między innymi dla rodzin syryjskich Ormian rozdartych przez konflikt wojenny.

Kończąc, warto wspomnieć, że sami syryjscy Ormianie usiłują pomagać sobie nawzajem i nagłaśniać społeczeństwu ormiańskiemu swoje problemy. W Armenii stworzyli własne stowarzyszenie (Unia Syryjskich Ormian), które współpracuje z wieloma organizacjami pozarządowymi. Wreszcie, społeczność syryjskich Ormian aktywnie udziela się w mediach społecznościowych. Dzięki nim stworzono takie grupy, jak: Skrzyżowanie, Wsparcie dla Syryjskich Ormian Ormianie z Aleppo. Chociażby poprzez Facebooka żywo dyskutują na temat tego, co dzieje się teraz w Syrii, podtrzymują kontakty z tymi, którzy zostali w kraju, i zastanawiają się, jak mogą im pomóc, a także omawiają problemy, które towarzyszą im na co dzień w Armenii.

\section{Uwagi końcowe}

Syryjscy Ormianie, którzy znaleźli się w Armenii, napotkali wiele problemów. Ich wyobrażenia o ojczyźnie sprzed wojny w Syrii zostały boleśnie skonfrontowane z rzeczywistością. Armenia, do której przyjechali nie z własnego wyboru, nie była ojczyzną, o której marzyli. Szczególnie dla tej części syryjskich Ormian, którzy zdążyli już wyemigrować z Armenii do innych krajów, dalsza podróż wiązała się z wyraźnym kryzysem świadomości narodowej.

Warto w tym miejscu przytoczyć słowa Firdasa Zakarayana, szefa sztabu w Ministerstwie Diaspory, który powiedział: „Oczywiście, istnieją ludzie, którzy nie są zadowoleni z pomocy, którą otrzymują, ale gdzie indziej żyją w namiotach. Czy można te warunki z sobą porównywać?”. Dalej dodał, „Syryjscy Ormianie zostawili swoje domy, swoje rodziny, dobre posady. Jak mogą być tutaj szczęśliwi w każdych okolicznościach?" (Schwartzstein 2015). Władze w Erywaniu zniosły opłaty wizowe, uprościły procedury otrzymania obywatelstwa, ułatwiły podróż do Armenii. Dla niektórych syryjskich Ormian to jednak zbyt mało. Jako potomkowie ocalałych z ludobójstwa Ormian, którzy przeżyli marsze śmierci, chroniąc się w Syrii, oczekiwali więcej od swoich armeńskich pobratymców. Proces integracji w historycznej ojczyźnie okazał się trudny dla obu stron.

Wielu syryjskich Ormian wierzy, iż wojna w Syrii wkrótce dobiegnie końca i będą mogli wrócić do swoich domów. Niektórzy, jak członkowie kilku rodzin 
z Aleppo, z którymi rozmawiałem w Erywaniu, byli już spakowani na powrót do Syrii. Poczucie tymczasowości nie ułatwia asymilacji.

Choć zabrzmi to paradoksalnie, wielu syryjskich Ormian mentalnie nigdy nie wyjechało z Syrii. Niektórzy dokładają wszelkich starań, aby bardzo dokładnie odtworzyć swoje dawne życie w Erywaniu - knajpki, warsztaty czy sklepy przypominają do złudzenia te, które posiadali w Aleppo czy Damaszku. Restauracje oferują kuchnię lewantyjską, nieznaną dotąd w Armenii, wiele centrów handlowych zawiera w nazwie „Aleppo”, na drzwiach sklepów, zakładów fryzjerskich i barów zostały umieszczone tabliczki z napisem „Tutaj pracują syryjscy Ormianie”. Oczywiście, trudno nie zauważyć i tym samym nie doceniać pozytywnego wkładu uchodźców syryjskich w życie społeczno-gospodarcze Armenii. To właśnie ta grupa przyczyniła się do ożywienia armeńskiej gospodarki i przedsiębiorczości w ostatnich latach. Rynek nieruchomości, drobnego handlu i usług najszybciej odczuł korzystne zmiany. Wielu młodych ludzi rozpoczęło naukę w szkołach i na uniwersytetach w Erywaniu, które od dłuższego czasu borykały się z radykalnie zmniejszającą się liczbą studentów. Został wyhamowany trend depopulacyjny, a Armenia zmagająca się z emigracją członków własnego narodu zyskała nowych obywateli, niemniej jednak pytania o to, co stanie się dalej z syryjskimi Ormianami oraz jaka jest ich przyszłość w Armenii, dziś pozostają otwarte.

\section{Bibliografia}

Abel T.

1948 The Operation Called Verstehen, „American Journal of Sociology”, t. 54, s. 211218.

Berry J.W.

2006 Contexts of Acculturation, w: The Cambridge Handbook of Acculturation Psychology, Cambridge, s. 27-43.

Campos N.M.

2016 Historical Trauma and Refugee Reception: Armenians and Syrian-Armenian Co-Ethnics, https://repository.usfca.edu/cgi/viewcontent.cgi?article=1260\&context=thes (dostęp 08.09.2017).

Chatty D.

2017 Syria. The Making and Unmaking of a Refuge State, London.

Davtyan A.

2017 The Dilemma of Syrian Armenians. Between Refugees and Repatriates, http://www. noravank.am/eng/articles/detail.php?ELEMENT_ID=15830 (dostęp 14.10.2017).

Fedorak S.A.

2017 Anthropology Matters. Third Edition, Toronto.

Fedorowicz K.

2017 Transformacja ustrojowa w Armenii w latach 1991-2016, Poznań. 
Grajewski A.

2017 Nowy exodus Ormian, http://gosc.pl/doc/3712213.Nowy-exodus-Ormian (dostęp 08.09.2017).

Ghoill D.M.

2013 The "Arab Spring” and the Seduction of the Western Left, https://zeroanthropology.net/2013/08/26/the-arab-spring-and-the-seduction-of-the-western-left/ (dostęp 06.09.2017).

Górak-Sosnowska K.

2016 Arabska Wiosna. Kulturowy obraz przemian w świecie arabskim po 2010 roku, Sopot.

Hakobyan A.

2014 Syrian-Armenians in Armenia: Repatriates or Refugees?, Yerevan (maszynopis w posiadaniu autora).

Kubiak M.

2015 Syryjscy Ormianie wracają na Kaukaz, http://www.kaukaz.net/cgi-bin/blosxom. cgi/polish/syryjscy-ormanie (dostęp 07.09.2017).

Lust-Okar E.M.

1996 Failure of Collaboration: Armenian Refugees in Syria, „Middle Eastern Studies” vol. 32, nr 1, s. 53-68.

Migliorino N.

2008 (Re)Constructing Armenia in Lebanon and Syria. Ethno-Cultural Diversity and the State in the Aftermath of a Refugee Crisis, London.

Nieczuja-Ostrowski P.

2016 Diaspora ormiańska $w$ Polityce Armenii: relacje i obszary oddziaływania, w: Armenia. Dziedzictwo a współczesne kierunki przemian kulturowo-cywilizacyjnych, red. P. Nieczuja-Ostrowski, Poznań, s. 145-186.

O’Rurke J.

2015 Education for Syrian Refugees: the Failure of Second-Generation Human Rights During Extraordinary Crises, http://www.albanylawreview.org/Articles/Vol78_2/78.2.711\%20 ORourke.pdf (dostęp 07.09.2017).

Pashayan A.

2009 Problems of the Armenians of Syria: the Armenian Community of Damascus, http:// www.noravank.am/eng/issues/detail.php?ELEMENT_ID=3702 (dostęp 12.09.2017).

Payaslian S.

2007 The History of Armenia, New York.

Safran W.

2005 The Jewish Diaspora in a Comparative and Theoretical Perspective, „Israel Studies” vol. 10, nr 1, s. 37-60.

Schwartzstein P.

2015 Syrian Refugees in Armenia 'Stumble from one Crisis to Another', https://www. al-monitor.com/pulse/originals/2015/07/syrians-displaced-armenia-origin-situation. html (dostęp 10.10.2017).

Siekierski K.

2014 Armenia: kultura współczesna w ujęciu antropologicznym - wprowadzenie, w: Armenia: kultura współczesna w ujęciu antropologicznym, red. L. Abrahamian, K. Siekierski, Warszawa, s. 11-17. 
Stepanian A.

2014 Armenia: od ojczyzny mitycznej do rzeczywistej, przeł. J. Ozimek, w: Armenia: kultura współczesna w ujęciu antropologicznym, red. L. Abrahamian, K. Siekierski, Warszawa, s. 35-50.

Szagojan G.

2014 Pamięć o trzęsieniu ziemi w Giumri, przeł. J. Ozimek, w: Armenia: kultura współczesna $w$ ujęciu antropologicznym, red. L. Abrahamian, K. Siekierski, Warszawa, s. 119-140.

Ter-Grigoryan H.

2013 Adaptation Problems of Syrian Armenians in Armenia, Erywań. Totah F.M.

2017 The Syrian Regime and the Opposition, https://www.huffingtonpost.com/american-anthropological-association/the-syrian-regime-and-the_b_1392023.html (dostęp 06.09.2017).

van Dam N.

2011 The Struggle for Power in Syria: Politics and Society Under Asad and the Ba'th Party, New York.

Vertovec S.

2012 Transnarodowość, przeł. I. Kołbon, Kraków.

Wróbel J.

2017 Armenia - kraj uchodźców. Tysiące syryjskich Ormian powraca na ziemię przodków, http://www.eastbook.eu/2017/02/13/armenia-kraj-uchodzcow-tysiace-syryjskich-ormian-powraca-na-ziemie-przodkow/ (dostęp 07.09.2017).

Zakrzewska-Dubasowa M.

1990 Historia Armenii. Wydanie drugie poprawione i uzupetnione, Wrocław-Warszawa-Kraków. 